Mediterranean Journal of Humanities mjh.akdeniz.edu.tr I/2, 2011, 127-134

\title{
Mehmet II’s Campaign to Italy (1480-1481)
}

\author{
II. Mehmet'in Italya Seferi (1480-1481)
}

\section{Haldun EROĞLU*}

\begin{abstract}
Mehmet II's military campaign to Italy was the first and the last attempt at conquest on the coast of the Adriatic Sea. Different views have been asserted about the political, military and economic reasons for the conqest of Italy between the years 1480-1481. In this study, Mehmet II's understanding of Emperorship and the effects of his policy of religion on his campaign to Italy were researched. With the conquest of Istanbul, Mehmet II started to use the title "The Protector of Orthodox Christians and the Emperor of Eastern Rome”. With his military campaigns to Italy, Mehmet II aimed at being the ruler of the Catholic world and of ancient Rome. After the conquests in the Balkans, Mehmet II reached the coast of the Adriatic Sea. He aimed at conquering Italy which was the centre of the Roman and the Catholic world at that time. In order to reach his goal he charged Ahmed Gedik Pasha with this task. With the conquest of Otranto, Italy began to be conquered. However, with the death of Mehmet II, in 1481 the conquest of Italy was not realised.
\end{abstract}

Keywords: Italy, Mehmet II, Gedik Ahmet Pasha, Otranto

Özet: II. Mehmet'in İtalya seferi, Osmanlı İmparatorluğu’nun Adriyatik Denizi'nin karşı kıyılarına yaptığ1 ilk ve son fetih girişimidir. 1480-1481 tarihleri arasındaki İtalya seferinin, siyasi, askerî ve ekonomik gerekçeleri konusunda farklı görüşler ileri sürülmüştür. Bu çalışmada, II. Mehmet'in imparatorluk anlayışıyla din politikasının, İtalya Seferi'ne etkileri ele alınmıştır. İstanbul'un fethiyle birlikte Ortodoks Hristiyanlarının koruyucusu ve Doğu Roma İmparatoru sıfatını kullanmaya başlayan II. Mehmet, İtalya seferiyle de Katolik dünyasının ve antik Roma'nın hâkimi olmayı hedeflemiştir. Bu amaçla Balkanlarda gerçekleştirilen fetihlerle Adriyatik kıyısına ulaşan II. Mehmet için yeni hedef Roma ve Katolik dünyasının merkezi İtalya'dır. Bu amacına ulaşmak için Gedik Ahmet Paşa görevlendirilmiş, Otranto’nun fethiyle birlikte İtalya ele geçirilmeye başlanmış; ancak II. Mehmet'in ölümü İtalya'nın fethinin yarım kalmasına sebep olmuştur.

Anahtar sözcükler: İtalya, II. Mehmet, Gedik Ahmet Paşa, Otranto

The historical realities underlying the fact that the Ottomans transformed into a massive empire only 150 years after they emerged in northwestern Anatolia toward the end of the $14^{\text {th }}$ century have not been completely illuminated. This because the strategies and policies followed during this period, although they constituted the basis of Ottoman expansion and sovereignty until the middle of the sixteenth century, triggered the decline of the empire. Undoubtedly, the transforming of a powerful state into an expansive empire took place during the reign of Mehmet II (14511481). In fact, in the second year of his reign, Mehmet's conquest of Istanbul (May 29, 1453) was of vital importance since it revealed that he had much greater ambitions. The conquest of Istanbul was not only Mehmet II or the Ottomans' project but also of the Turks' who arrived in Anatolia from the $11^{\text {th }}$ century. We can argue that this aim became an essential and ultimate

\footnotetext{
* Prof. Dr. Akdeniz Üniversitesi, Edebiyat Fakültesi, Tarih Bölümü, Antalya, halduneroglu@akdeniz.edu.tr
} 
purpose of the Ottomans taking into account the regions they had been conquering and deploying in (Eroğlu, 2007, 117-131).

Furthermore, we cannot limit our approach to the policy followed for the conquest of Istanbul by assuming that it was merely a dream of conquering the Byzantine capital. Because analyzing the conquest of Istanbul is extremely important to understanding post-conquest Ottoman policies.

The Rumelian conquests launched by Ottoman Prince Suleiman Pasha during the reign of Orhan Bey gained much greater importance and a new phase with the conquest of Istanbul. With this phase, the Ottoman expansion reached along the Adriatic coast after the conquest of Albania in the last quarter of the $15^{\text {th }}$ century. Generally, the expansion of the Ottoman Empire is discussed in terms of it growing larger and the seizure of all the Christian states/statelets standing against it, mainly in terms of the geographic continuity of the conquests. Thus, the expedition to Italy, which is the main focus of this study, has been considered as a natural consequence of the Ottomans' reaching the Adriatic coast and the geographic continuity of the conquests. It is remarkable that the matter is reflected in the Ottoman sources in this manner. For instance, Hoca Saadettin, author of the Ottoman chronicle called Tacü't-Tevarih, attributes Mehmet's expedition to Italy to the fact that Gedik Ahmet Pasha, who was appointed to conquer Avlonya (Vlorë) in order to eliminate the resistance in Albania, asked for permission to conquer Polya (Apulia) since it was adjacent to the Avlonya district and Hoca Saadettin further explains that Gedik Ahmet Pasha was granted permission as well as funds, troops and naval forces to conquer Otranto (Hoca Saadettin, 1979, 164-165). Şerafettin Turan claims that İdrisî Bidlisî shares the same opinion but Hammer suggests that Mehmet the Conqueror was encouraged to launch this expedition by the Venetians (Ibn Kemal, 1991, 507). According to Hoca Saadettin, the reason why the Ottoman troops attacked Italy was the fact that Gedik Ahmet Pasha wanted to seize the opposite coasts of the Adriatic Sea acting in accordance with the notion of continuity of the conquest.

On the other hand, a quick look through the Ottoman chronicles reveals that Mehmet's expedition to Italy is not mentioned comprehensively in the chronicles. It is a matter of debate to claim that the chronicles do not provide detailed information about the campaign because they did not attach importance to the conquest of Otranto. On the other hand, we need to focus on the reasons why the Ottoman sources remain silent about the expedition to Italy and the conquest of Otranto while they provide profound information about seizure of even a small town in the Balkans or Anatolia.

M. Neşri $(1995,839)$ mentions the expedition to Otranto in a few words: "Hünkar, Gedik Ahmet Paşa'y Polya'ya gönderdi. Ve Gedik Ahmet, Poyla vilayetine ehl-i İslamdan mübalağa adam geçürüb, birkaç pare kale feth etti. Ta Hünkar ahirete nakl edince Polya'da kalıp hayli fütuhlar ede başladı”. The information in Oruç Bey (Oruç Bey Tarihi, 1972, 129), Lütfî Pasha (1341, 190) and other anonymous Ottoman chronicles (Anonim Osmanl Kroniği, (1299-1512), 2000, 130, Anonim Tevârih-i Al-i Osman, 1992, 118) is no more detailed or different from this. Moreover, Tursun Bey $(1977,180)$, a contemporary historian to Mehmet II, provides very little information about the expedition to Italy in his book called Tarih-i Ebu'l-Feth: "Binaberin ma'na Gedik Ahmet Paşa'yı sene erbâ 'in ve semânîne ve semânî mi'e tarihinde, azim tonanma ile Pulya ceziresine saldr. Varup, bi-inâyeti'l-lah ve bi- himmeti Sultanı zıllu'llah, nefs-i kal'a-i Pulya'yl -ki madend-i kal'a-i Konstantiniyye'dür-kahr ile fet itti ve çok memleketini zapt itti. Ma'abid-i asnâm mesâcid-i İslâm olub penç nevbet-i Muhammedî 'aleyhi efdalü's-selâm çalındı”. As an exception, Ibn Kemal (1991, 507-520), unlike other chronicles, provides detailed information about the expedition to Italy.

Although it did not receive an adequate echo in the Ottoman chronicles, we should analyze the political and military aspects of the period that ended with the conquest of the opposite coast 
(Pulya Island) of the Adriatic and the withdrawal of Ottoman military forces after the death of Mehmet in order to shed light on the matter. Because, Mehmet's expedition to Italy was the first yet the last military campaign to Italy in Ottoman history. Furthermore, the region was not/could not be included in the later conquest areas although the expansion of the empire continued. Although there are several views claiming that Suleiman's Corfu expedition (1537) aimed at the invasion of Italy at the beginning of the campaign (İnalc1k, 1997, vol. I-298), neither those views were confirmed nor was the conquest realized. Therefore, even this fact attributes a vital importance to the motive which caused Mehmet II to launch the Italian campaign.

N. Iorga (2005, vol. I-127) states that Avlonya, which would lead the attack to Otranto, had been fortified and garrissoned with four hundred Janissaries in the year 1466. In 1470, Mehmet II conquered Euboea Island (called Eğriboz by the Ottoman Turks) after informing the King of Naples, thus causing the severance of relations between the Ottomans and the Venetians. Consequently, the King of Naples declared that he would fight against the Ottomans in an alliance with Venice and Spain. Shortly after the King of Naples had severed relations with Venice, he established good relations with the Ottomans again (Uzunçarş111, 1961, 595). Having reestablished good relations with the Venetians as well as with the King of Naples, Mehmet II began preparations for an expedition to Italy. He declared the reason for this campaign was because Loredano Tocco, Prince of Lefkada, Zakynthos and Kefalonia islands, had ceased to pay tax to the Ottomans (Uzunçarş11, 1961, 595). As the other princes in Italy were having an intense struggle among themselves, Mehmet II found an excellent opportunity to implement his policies. Besides, his spies and commanders were constantly informing him about the news from Italy. As a matter of fact, Iskender Pasha, in one of the letters he sent, stated that Pulya Island was rather vulnerable to be conquered and he gave detailed information about Italy. For the expedition to Italy, Gedik Ahmet Pasha set out with a total of one hundred and thirty-two vessels, twenty-eight of which were galleys (Tansel, 1999, 217-219). Ibn Kemal, in relation to this matter, wrote these lines:

“Ahmet Paşa, mezkur hisarun harabını mamur ettikten sonra, tamam
nevahisiyle zabt idüb diyar-ı islama rabt idüb darü'l-mülk idindi, derya-
barun cevşerver ve hançer-güzar ve nize-dar sipahilerini ki ol diyar bahr
idi anlar mahilerdi, şikar eylemek içün fülk idindi. Ol kenar da gezüb bir
nice pare şehr ve hisar dahi feth etdi. Küffarın direngin sezdüğ̈̈ yere
leşker-i cerrar gönderüb tağıttı ol diyarı kendüye uc idünüb yakın
yerlerine akın gönderdi her gün bir kenara hurucı iş güç idinüb darü'l-
küfrün altın üstine dönderdi” (Ibn Kemal, 1991, 508-510).

Gedik Ahmet Pasha, who had set out for the expedition to Italy, headed to the city and fort of Otranto ruled by King Ferdinand of Naples and he conquered Otranto on August 11 ${ }^{\text {th }}, 1480$. Aiming to conquer all of Italy, Ahmet Pasha did not settle with the conquest of Otranto and he continued to march into Italy in order to conquer and seize new lands. However, unfortunately, upon the death of Mehmet II on May $19^{\text {th }}$, 1481, Bayezit acceded to the throne (Ibn Kemal, 1991, 511, 513, 518) and he recalled Gedik Ahmet Pasha to Istanbul. The Pasha returned to Istanbul leaving a garrison of 8000 infantry behind to defend Otranto as well as enough supplies meant to suffice for one and a half years (Uzunçarş111, 1961, 595-596). It is recorded in some of the Ottoman resources that Gedik Ahmet Pasha assumed that he would return after the winter but upon the death of Mehmet II, he did not return to Otranto (Mustafa, Nuri, Paşa, 1992, vol. III 50). In 1481, an army raised by King Ferdinand I of Naples besieged the city of Otranto. Ibn Kemal records that the siege lasted for six months and since the Ottoman soldiers in the castle did not receive any reinforcements, they had to eat even the cats and dogs in the castle (Ibn Kemal, 1991, 519). 
Due to Gedik Ahmet Pasha's return to Istanbul and the ensuing subsequent quarrels about Ottoman prince Cem's succession, the possible conquest of Italy halted. Since Bayezit's II father abandoned the policy of the conquest of Italy, the King of Naples decided to end the Turkish occupation of Otranto. For this purpose, he asked for assistance of King Matthias Corvinus of Hungary. A contingent of 2.000 cavalry troops was provided by the King of Hungary and they besieged the castle. Ottoman troops, since no reinforcements were sent to assist them, had to surrender the castle by negotiation with the Christian forces on the condition that they would be permitted to withdraw with their weapons remaining intact (August 10, 1481). However, they were still taken captive when the Christian troops again occupied Otranto (Uzunçarş1l1, 1961, 596). Neşrî (1995, vol. II-839) quotes: "andan sultan Mehmet vefatından sonra, Gedik Ahmet, Sultan Bayezlt'e istikbale gelicek, ol Müslümanlara kafir anda çok iş etti. El-hasıl Polya'yı yine kafir alıp, anda olan Müslümanların kimi öldü, kimi bin türlü belaya halas oldu". N. Iorga (2005, vol. II-237), unlike Uzunçarş1lı's statement of 8.000 captive soldiers, notes that only 2.050 Ottoman soldiers were taken captive, but 500 of these Turks were assigned to participate in the army of the King of Naples and they fought many battles with this army.

After settling the Prince Cem issue, Bayezit II sent legates to the King of Naples proposing a settlement for returning the captive soldiers and weapons (Ibn Kemal, 1991, 520). As a result of the agreement, the Ottoman janissary troops and captured weapons were returned. The Ottoman policies on Italy ended by signing the treaty requiring a price to be paid in exchange for releasing the Ottoman troops. The words of the King of Naples addressing to the released soldiers are quite interesting and are noteworthy in respect to revealing the Ottoman impact in Italy. Ibn Kemal $(1991,520)$ quotes that the King of Naples said these words while sending the Ottoman troops off his lands: "Bu diyara geldiğünüzden ne ziyan gördünüz? Nice kere düşmen cemiyetin tağıttunuz, bunca zaman hazz-l vafir ettinüz, sefalar sürdünüz. Ziyan bana oldu ki vilayetüm garet old, ilim günüm yakıldı ylkıldl, hasaret oldu. Raiyyet halkından gayri benden dirlik yer, on bir bin sipahi sizünle mukabelede mukatelede getdi, telef oldı. Nize-i sitizle pür-niş ve ruyin-i kinle dil-niş olub Hüsam-ı intikama alef ve tir-i tedmire hedef oldı. Ölen öldi, olan oldl. Gelün, geçenden geçelüm, şimden gerisün görelim. Elem-i müsadefeyi ber-taraf idüb alemi müsadakadan dem vuralum”.

As reflected in the words of the King of Naples, that the Ottomans conquered the coasts of Italy crossing the Adriatic Sea made a great impact upon the Christian world. The impact on the Christian world caused by about a year-long domination of Otranto, although hardly reflected in the Ottoman sources, it is widely expressed in contemporary Greek sources. In fact, numerous comments and views recorded in these sources claimed that the death of Mehmet II, which caused Gedik Ahmet Pasha to cease conquests in Italy and return to Istanbul, saved Italy and the Christian world view, many sources for this can be found (Grekçe Anonim Osmanlı Tarihi, 1973, 173).

All Ottoman chronicles note that the underlying reason why Mehmet II launched the Italian campaign was the duty to spread Islam as it is the main motive of all other Ottoman conquests. Ibn Kemal $(1991,507)$ expresses the idea in these words: "Hazret-i hüdavendigar, sipehsalarkişver-küşa Gedik Ahmet Paşa'yı Kefelonya'yı ve Avlonya'yı aldıktan sonra buyurmuştu ki varub Polya diyarın dahi teshir idüb a'day-ı deb-reyi def eyleye; leşker-i cerrar-ı nusretasarlaşevket-i küffar-ı bed-sireti kesr idüb rayet-i feth-ayet-i İslam-ı zafer encam-ı nasbetmekle ol vilayeti darü'l-islama zam idüb içinden şiar-ı küfri ref eyle”.

Selahattin Tansel (1999, 217), who conducted a study mainly focusing on Mehmet II, does not give a clear explanation concerning the reason for the Italian campaign: "Venedik sulhunu yapar yapmaz, ötedenberi düşündüğ̈̈ halde bir türlü yapmaya muvaffak olamadığını tahmin ettiğimiz İtalya Seferine hemen başladı". However, K. Giakoumis, a contemporary author who 
wrote an article on the subject, suggests some opinions about the reasons why Mehmet II launched the Italian campaign. According to him, Albania was not the only country having Adriatic coasts. Epirus, which mostly lies today in modern Greek territory, was then an important location since it had a coast on the Adriatic Sea and overlooked the Gulf of Otranto. Therefore, it was crucial to capture Epirus for it was connecting the east and west. Another significance of this location was its dominance of the Gulf of Otranto. That made the province of Epirus a primary target to be held for the expansion of a new power in the Balkans or Italy. Whoever held this location could have the control over the straits and the opposite side. The Ottomans intended to seize and use Epirus as a shield against potential Christian attacks. K. Giakoumis (2002, 373-374) further claims that the Italian campaign was only a part of Mehmet's much greater ambitious plans. Therefore, it was inevitable that Italy became a natural target of Ottoman conquests after the occupation of the Balkan coasts of the Adriatic Sea.

On the other hand, Inalc1k considers that the Italian campaign was launched because Mehmet II set his sights on new territories to extend Ottoman sovereignty after he had strengthened the empire's hegemony over Rumelia and Anatolia, reached the River Danube in Balkans and who made it the northern border from Belgrade to the Black Sea, and expanded the eastern borders to the River Euphrates. According to him, it was posing a serious threat for Ottoman sovereignty that the Venetians were still holding the Morea and the Albanian coast and some points in the Aegean, the Hungarian ruled Belgrade and northern Bosnia, Moldavian Prince Stephen the Great had strength over the Black Sea and the lower Danube. At the same time, the Knights of Rhodes, by order of the Pope, maintained their position as outpost for a crusade. In fact, the Pope, preparing to go to France, had called for aid by all the states in the western Christian world. For all the above reasons, Mehmet II regarded the Italian campaign as a necessary action to be taken (İnalc1k, 2004, 34).

In addition to the above reasons, the fact that Leonardo, ruler of the islands near Epirus and paying tax to the Ottomans every year, married the Princess of Naples without obtaining permission from the Ottomans is suggested as one of the reasons why the Italian campaign was launched (Uzunçarş111, 1994, vol. II-135, Tansel, 1999, 219).

The aforementioned remarks merely explain the political and military motives of the expedition to Italy. However, these political and military reasons should not prevent us from seeing another side to the conquest. This because, Mehmet II declared himself protector of the Orthodox Church and of millions of Orthodox Christians just after he had conquered Istanbul in 1453 so that he could legitimize his rulership over the Christian citizens under Ottoman rule. In addition, Mehmet II adopted a policy where he neither allowed religious or ethnic discrimination between Jewish and Christian citizens under his rule nor granted privilege to either one. However, he attached some priorities to certain groups in the treatment of non-Muslim minorities as they had political, social and economic effects over the fundamental interests of the empire and the people. The most prominent of these groups were Armenians, Serbians and Ottoman Greeks (Rum). Thus, a clear, certain and systematic policy conducted with non-Muslim minorities became definite during the reign of Mehmet II (Ercan, 2004, 9).

On the other hand, Mehmet was trying to make Istanbul the religious center of the Orthodox Christian world. After the conquest, scattered Orthodox Greeks re-organized, Gennadios II Scholarios was appointed patriarch and designated as the spiritual leader as well as the ethnarch of all the Orthodox Christians in the Empire. During this period, the Orthodox Christians in Egypt, Syria, Palestine, Cyprus and Russia as well as in Rumelia and Anatolia came under the spiritual and administrative jurisdiction of the Patriarchate (Ercan, 2001, 103-104).

Besides, in a similar way, Mehmet aimed to establish a legitimate rule over the Catholics with the Ottoman conquest of the Balkans. In that way, he could have captured and given 
perhaps the best punishment to the Papacy, which was constantly launched crusading expeditions and called for Christian alliance against the Ottomans during the conquest of the Balkans.

On the other hand, although there is no record in the Ottoman chronicles about this matter, the Anonymous Ottoman History, a book written in the Greek language, notes that Mehmet desired to conquer Italy, Europe (Frengistan) as he knew if he had captured Rome, he could have claimed the title of "Caesar" of Rome (Kayser-i Rûm) (Grekçe Anonim Osmanlı Tarihi, 1973, 171). Mehmet II declared the title of 'Great Emperor of Rumelia and Anatolia' or "Asie et Gretie Imperator" (Iorga, 2005, 55). It is noteworthy that a messenger of the Cypriot Palace, while trying to appeal for aid against the Ottoman Turks, said: "yeni Roma'nın kafir yeni imparatorunun kibirli ve parlak sözler ile eski mukaddes Roma'y papazların elinden alıp cihan imparatorluğunu Osmanlı biçimine uygun bir şekilde tekrar kurmak ve zamanın Büyük İskender'i unvanına sahip olduğunu göstermek için yanıp tutuştuğunu” (Iorga, 2005, 55; Eroğlu 2006, 44).

We could suggest that the policy Mehmet II adopted might have resulted in eliminating the division of Christianity into Catholicism and Orthodoxy, also known as the Great Schism, and enabled a reunion of Christianity. In other words, if the expedition to Italy had been successful and Italy had been conquered, the conflict in the Christian world could possibly have been settled by a Muslim-Turkish king, which might have been a paradox in the history books. However, none of these objectives could be realized due to the death of Mehmet II.

Here, we need to mention briefly the history of Great Schism (the division between the Latin and Greek churches) in the Christian world. Because the division and deep conflict between Latin Catholic Church and Greek Orthodox Church still continues to be an unresolved issue and a matter of debate in today's Christian world.

The first significant division between Rome and Istanbul occurred in 381 A.D. during the Second Ecumenical Council, held in Istanbul which was declared the new capital in 324 A.D. (see also Arslan 2010, 11 fn. 30; 432-433 fn. 1788) by the Roman Emperor Constantine the Great (306-337). In this council the Bishop of Rome claimed that Rome should have been the 'successor of blessed Peter' since the Roman Church was founded by Saint Peter, the new order should take into account this fact in respect to the church hierarchies. In addition to this problem, when Theodosius I, died in 395, he divided the Roman Empire between his sons, it brought about disagreements and power struggles. After the General Council in 381, where the first signs of separation had occurred, the Council of Chalcedon in 451 declared the authority of the Istanbul Church and raised the See of Constantinople to a position of honor and authority equal to that of Rome. However, the nearly immediate result of the council was a major schism when the Roman Church did not recognize the canon granting Istanbul equal privileges to Rome. In the $6^{\text {th }}$ century, the patriarchs of Istanbul began using the title Ecumenic and Rome did not recognize this title, which magnified the schism even more. After the Slavic people in the Balkans had adopted Christianity, Latin and Greek cultures were divided in the form of Catholic and Orthodox Christianity. The two halves of the Church were naturally divided along similar lines; they had different approaches to religious teachings. Thus, while the primary causes of the schism were disputes over conflicting claims of jurisdiction, different approaches to religious doctrines deepened the schism. In addition to all the matters mentioned above, both churches developed different rites and symbolic practices, which increased tensions. For example, the Roman church asked the Orthodox to shave their beards but the Orthodox clergy refused to shave their beards, as they regard it as the symbol of the Greek philosophers, who retained the beard as a badge of their profession. That the Roman Church insisted on their tradition of shaving their beards caused another aspect of the political and doctrinal schism to emerge, which was division in the exercises. This latter separation embittered the conflict between Rome and Istanbul. Hence, the schism in the Christian world, which had been subject to controversy 
and debates between east and west for 700 years was actually consummated when this sequence of events took place (Kaçar, 30 Kasım 2006, Radikal Gazetesi).

It is noteworthy that, although the Christian world was suffering from this permanent schism, they managed to maintain the Spirit of Crusade and took a stand against the Ottoman military campaigns launched to seize Christian Balkan lands. The papacy in Rome played a major role in establishing the Spirit of Crusade against the Ottomans. The Christian world put the schism aside and acted together through crusader spirit to defend against the Ottoman campaigns launched on either Catholic or Orthodox countries. It is recorded that the Battle of Kosovo (1389), Battle of Nicopolis (1396), Battle of Varna (1444) and Second Battle of Kosovo (1448) were regarded as Crusades called by the Pope against the Ottoman Turks. Without doubt, the underlying reasons for these battles were not religious but political. In fact, the Orthodox-Catholic alliance established by so-called religious motives was a military and political alliance aiming to halt the Ottoman expansion in the Balkans.

In conclusion, having conquered Istanbul and transformed his state into a multilingual, multireligious and multicultural empire through the correct policy he had adopted, the MuslimOttoman Emperor Mehmet II launched the Italian campaign to capture Rome and to take control of the Catholic Church. Perhaps, in this way, the Great Schism might have been settled and the Christian world could have moved forward to reconciliation. Mehmet II intended to retain control over the spiritual leadership of the Catholic world through capturing Italy as well as keeping the Orthodox Christians under his rule. Because, the main purpose of Ottoman world domination was to gather different religions, languages and ethnic structures under "Osmanlıllk İdeolojisi (The Ideology of Ottomansim)" (Eroğlu, 2006, 37-51).

Further, with the conquest of Istanbul, Mehmet II claimed the title of Emperor of the Roman Empire because he thought of himself as the heir to the throne of the Roman Empire. As a matter of fact, if we evaluate the reactions of the Christian world in this respect, which were reflected in the Christian sources, Mehmet's Italian campaign had different implications from those recorded in the Ottoman sources. Whereas, the wording of the Italian campaign in the Ottoman chronicles is full of Islamic patterns and concepts. One of the explanations for this tendency we can provide is that Muslims tended to reflect their reactions in a significant Islamic manner of expression while non-Muslim citizens gained an increasing socio-economic significance in Mehmet's multilingual, multinational and multicultural empire model. In fact, authors of chronicles with a background in Islamic tradition reflected their reactions in a clear manner (Eroğlu, 2007, 245-262).

As concluding remarks, we can suggest that the real motives underlying Mehmet's Italian campaign, as well as the political, military and economic reasons, embodied the possible outcome of the religion policies he adopted to create a world empire. 


\section{REFERENCES}

Anonim Osmanlı Kroniği. (1299-1512), (2000). Haz. Necdet Öztürk. İstanbul: Türk Dünyası Araştırmaları Vakfı Yayınları.

Anonim Tevârih-i Al-i Osman. (1992). F. Giese Neşri-Haz. Nimet Azamat. İstanbul: Marmara Üniversitesi Fen-Edebiyat Fakültesi Yayınları.

Arslan, M. (2010). İstanbul'un Antikçağ Tarihi: Klasik ve Hellenistik Dönemler. İstanbul: Odin Yayıncılık.

Ercan, Y. (2001). Osmanlı Yönetiminde Gayrimüslimler, Kuruluştan Tanzimata Ekonomik, Sosyal ve Hukukî Durumları. Ankara: Turhan Kitabevi Yayınları.

Ercan, Y. (2004). Fatih'in Kilise Politikası. İstanbul'un Fethinin 550. Yll Anı Kitabı. Ankara: Ankara Üniversitesi Osmanlı Tarihi Araştırma ve Uygulama Merkezi Yayınları.

Eroğlu, H. (2006). Osmanlılar Yönetim ve Strateji. İstanbul: Gökkubbe Yayınları.

Eroğlu, H. (2007). Osmanlı Kroniklerinin Üslubuna Dair. Folklor Edebiyat Dergisi, 52, 245-263. Ankara.

Giokoumis, K. (2002). Osmanlıların Otranto ve Apulia Seferi (1480-1481). Türkler, cilt IX. Ankara. Yeni Türkiye Yayınları.

Hoca Saadettin. (1979). Tac'üt-Tevârih. Sad. İsmet Parmaksızoğlu, (cilt III). İstanbul: Kültür Bakanlı̆̆ı Yayınları.

Iorga, N. (2005). Osmanlı İmparatorluğu Tarihi (1451-1538), cilt II. İstanbul: Yeditepe Yayınları.

Ibn Kemal. (1991) Tevârih-i Âli Osman, VII. Defter. Haz. Şerafettin Turan. Ankara: Türk Tarih Kurumu Yayınları.

İnalcık, H. (1997). Osmanlı İmparatorluğu, Ekonomik ve Sosyal Tarihi (1300-1600). Çev. Halil Berktay. (cilt I). İstanbul: Eren Yayınları.

İnalcık, H. (2004). Osmanlı İmparatorluğu Klasik Çağ (1300-1600). Çev. Ruşen Sezer. İstanbul: Yap1 Kredi Yayınları.

Kaçar, T. (30 Kasım 2006). Katoliklerle Ortodoksların Ayrıllı̆g. Radikal Gazetesi.

Lütfî, Paşa. (1341). Tevârih-i Âl-i Osman. İstanbul: Matbaa-I Amire.

Mehmet, Neşrî. (1995). Kitâb-ı Cihân-nümâ. Yay. F. R. Unat, \& M. A. Köymen (cilt II). Ankara: Türk Tarih Kurumu Yayınları.

Mustafa, Nuri, Paşa. (1992). Netayicü'l- Vukuat. Sad. Neşet Çağatay, cilt I-II, Ankara: Türk Tarih Kurumu Yayınları.

On altıncı Asırda Yazılmış Grekçe Anonim Osmanlı Tarihi (1973). Haz. Şerif Baştav. Ankara: Ankara Üniversitesi Dil Tarih Coğrafya Fakültesi Yayınları.

Oruç Bey Tarihi. (1972). (Atsız neşri). İstanbul: Tercüman Matbaası.

Tansel, S. (1999). Osmanlı Kaynaklarına Göre Fatih Sultan Mehmet'in Siyasi ve Askerî Faaliyeti. Ankara: Türk Tarih Kurumu Yayınları.

Tursun Bey. (1977). Tarih-i Ebu'l-Feth. Haz. Mertol Tulum. İstanbul: Baha Matbaası.

Uzunçarşı11, İ. H. (1961). Otranto'nun Zaptından Sonra Napoli Kralı ile Dostluk Görü̈smeleri. Belleten, XXV, 100 596-608. Ankara: Türk Tarih Kurumu Yayınları.

Uzunçarşılı, İ. H. (1994). Osmanlı Tarihi. cilt II. Ankara: Türk Tarih Kurumu Yayınları. 